\title{
Effectiveness of Financial Risk Management Framework: An Analysis of the Mauritian Banking Sector
}

\author{
Lilesh Sookye, Aleesha Mohamudally-Boolaky \\ University of Technology, Mauritius, Port Louis, Mauritius \\ Email: aboolaky@umail.utm.ac.mu
}

How to cite this paper: Sookye, L., \& Mohamudally-Boolaky, A. (2019). Effectiveness of Financial Risk Management Framework: An Analysis of the Mauritian Banking Sector. Journal of Financial Risk Management, 8, 106-124.

https://doi.org/10.4236/jfrm.2019.82008

Received: April 28, 2019

Accepted: June 18, 2019

Published: June 21, 2019

Copyright $\odot 2019$ by author(s) and Scientific Research Publishing Inc. This work is licensed under the Creative Commons Attribution International License (CC BY 4.0).

http://creativecommons.org/licenses/by/4.0/

\begin{abstract}
The global economic meltdown caused by the subprime mortgage crisis in the United States in 2007 along with its subsequent adverse effects on the economy, financial participants around the world, have raised questions on the effectiveness of the financial risk management policies adopted by financial institutions and banks worldwide. This study focuses on the analysis of the risk management framework and its efficiency in the Mauritian banking sector. Panel regression and Non-parametric regression Lowess Smoother methodologies were employed in measuring the impact of the various financial risks on the efficiency of risk management of a sample of ten Mauritian banks over a period of eight years. The dependent variable selected to measure risk management efficiency is the Capital Adequacy Ratio (CAR). On the other hand, the financial risks indicators are the credit risk (CRisk), liquidity ratio (LQR), interest sensitivity ratio (ISR) and foreign exchange risk (FER). Both the parametric and non-parametric regressions indicate that the risk variables are significant and have a positive relationship on risk management efficiency. A dual approach has been employed through the administration of a survey to gauge into the perspectives and practices adopted by Risk managers in banks. Moreover, the findings obtained from the survey substantiated the main results. The methods used by the Mauritian banks and the importance of the Basel principles for effective risk management were also revealed by the questionnaires.
\end{abstract}

\section{Keywords}

Risk Management Efficiency, Financial Risks, Mauritian Banks, Capital Adequacy, Basel

\section{Introduction}

Banks focus more on maximising profits (usually short term objective), rather 
than consolidating their risk management frameworks which will contribute to the long term sustainability of a bank (Aremu et al., 2010). An analysis of the structure and mechanism of the risk management frameworks and practices of banks is therefore important to determine the adequacy of the systems, policies and procedures for managing risks. According to Abdalla \& Obeidat (2013) risk management in the banking sector plays a very important role in maintaining safety and solidarity of banks and prevents any unexpected loss that banks might face. Owing to the fact that banks operate in a highly uncertain environment which might lead to their exposure to the various risks, efficient risk management is a must. As preconized by the Basel Committee of Banking Supervision (BCBS), Banks can manage risks through Capital Adequacy Ratio (CAR) which acts as a cushioning mechanism for risk exposure of bank operations. The purpose of minimum capital requirement is to ensure that banks keep enough capital for the risks they take (Harris et al., 2014).

Mauritius has already implemented the Basel I and II frameworks and has now embarked on the implementation of Basel III rules to be in line with the international regulatory standards. Basel II was effective in Mauritius as from end March 2008 on a one-year parallel run with Basel I and was fully implemented as from end of March 2009. In the context of the Basel II implementation, banks had to apply both to the Guidance Notes on Risk Weighted Capital Adequacy Ratio (Basel I) and the Guidelines issued by the Central Bank. This was because, they maintained the Capital Adequacy Ratio at $10 \%$ while Basel II left the overall minimum capital requirements at $8 \%$ globally. In the consultation paper issued by the Bank of Mauritius (BOM) in 2012, the guidelines for implementation of Basel III in Mauritius were provided with respect to the capital Reforms, buffers and leverage ratios and Liquidity Reforms. The additional capital buffers introduced comprised of Capital Conservation Buffer and Countercyclical Capital Buffer, designed to be used in times of stress and to protect banking systems against risks involved with excess credit growth.

There is a strong assumption that the banking sector in Mauritius is reasonably stable with individual banks having healthy risk profiles and sound risk management practices. This belief originates from the fact that the industry has not witnessed heavy losses in regards to the recent global financial crisis. Additionally, the financial downturn which exposed the inadequacies of Basel II focussing on capital adequacy, has raised concerns among banking regulators if the minimum capital requirement is sufficient for Mauritian banks to absorb unexpected losses arising from financial risks. Taking all these factors into consideration, the question arises whether the risk position of the sector is strong enough to guard the interests of clients and shareholders, in the event of future crises. Therefore, a thorough analysis must be conducted to evaluate the adequacy of the risk management frameworks employed by the banks as well as to ascertain if the banking institutions are maintaining sufficient amount of capital to handle the various risks they are exposed to. 
The objectives of this study are to analyze the different types of financial risks faced by the Mauritian banking industry. It further examines the techniques adopted in order to mitigate or manage the risks outlined. It also highlights the efficiency of the risk management framework adopted by the Mauritian banking sector. The relationship between the risks identified and the risk management efficiency is observed as well as their impact of the financial risks on the risk management framework. Finally, the importance of the Basel framework within the banking economy and its contribution to the financial risk management is also depicted in the paper.

The rest of the paper is organized as follows. Section 2 is overview literature. The methodology adopted is described in Section 3 while the regression outputs and findings from survey are discussed in Section 4. Concluding remarks appear in Section 5.

\section{Literature Review}

\subsection{Types of Risks}

Credit risk management is considered as the most important risk management strategy in banking. Credit risk is measured for loans, guarantees and securities, such as corporate bonds, as well as for swaps and other off-balance transactions. Anbar (2006) conducted a survey to evaluate the credit risk management applications in the Turkish banking sector. The survey involved 48 banks which were national and foreign banks. There were three main quantitative credit risk measures; expected loss (EL), unexpected loss (UL) and credit value-at-risk (CVaR). He found that only $35 \%$ of the banks measured credit risk using these techniques. Furthermore, it was examined that $95 \%$ of the institutions used an internal credit rating system and a credit scoring model in credit risk analysis and credit measurement.

Eljelli (2004) defined liquidity risk as the risk arising when a bank is unable to meet short term financial demands when they fall due. Since commercial banks prosper on depositor's confidence, liquidity risk is decisive for their continued existence. Liquidity risks are usually measured by either liquidity gap analysis or by liquidity ratios. Bonfim \& Kim (2012) used a panel dataset of European and North-American banks for the period 2002-2009 to examine how banks measure and manage liquidity risk. They came to the conclusion that some banks adopted a globally prudent behaviour in managing liquidity risk, underlying their financial intermediation functions, whereas others engaged in more aggressive risk-taking strategies. They also found that large and banks with more profit adopted riskier liquidity strategies. On the other hand, banks with larger net interest margins and with better cost-efficiency ratios were less risky in their liquidity management.

Scannella \& Bennardo (2013) defined interest rate risk as unfavourable changes in a bank's economic and financial conditions due to adverse interest rate movement. Interest rate fluctuations can negatively impact a bank's income, 
market value and amount of financial intermediation.According to the Bank of Jamaica (2005), each bank needs to establish explicit and prudent interest rate risk limits, and ensures that the level of interest rate risk exposure does not exceed these limits. Burke \& Warfield (2014) used a sample of bank holding companies from 1997 to 2011 and examined the banks' interest rate risk management and its effects on the persistence and valuation of banks' earnings. They found that banks with the ability to enhance yields on assets and reduce funding costs through interest rate risk management strategies are more likely to have persistent net interest income.

Foreign exchange risk is originated when a bank holds assets or liabilities in foreign currencies and impacts the earnings and capital of the bank due to fluctuations in the exchange rates (Papaioannou, 2006). The commonly used method to predict the riskiness of a foreign exchange position is the value-at-risk (VaR). Sabri (2011) explored different aspects of foreign exchange risk management by commercial banks of Pakistan and showed that the banks used different techniques to manage foreign exchange risk which include foreign currency portfolio diversification, foreign currency assets, liabilities match and use of derivatives.

\subsection{Capital Adequacy as Indicator of Risk Management Efficiency}

The Basel Committee of Banking Supervision (BCBS) stresses the importance of capital adequacy, where banks' internal risk models are implemented such that capital augmentation can cover for possible consequences of risk-taking (Ojo, 2008). Risk management encompassing bank capitalisation strategies is therefore important in evaluating the likelihood of bank distress. This is confirmed by Berger \& Bouwman (2013) who stated that a higher level of pre-crisis capital reduces a bank's probability to fail in a banking crisis. Beltratti \& Stulz (2012) averred that banks which were better capitalised before the crisis had a better stock-market performance during the crisis.

In April 2015, BOM revoked the license of the Bramer Banking Corporation Ltd because of liquidity problems faced by the latter. It experienced difficulties in maintaining its cash reserve ratio imposed by the regulator. Later, it was observed that the bank was subject to massive withdrawal in deposits and its liquidity position was worsening. It did not have sufficient capital requirement to satisfy its liquidity position. According to the BOM, Bramer Banking Corporation Ltd was under-capitalised and not in a position to rectify its financial situation. Therefore, the bank's license was revoked owing to serious impairment in its capital and failure to demonstrate its ability to address capital and liquidity issues in accordance to the BoM's requirements.

Al-Sabbagh (2004) describes capital adequacy as an indicator of bank's risk exposure. Therefore, regulatory authorities use CAR as a significant indicator of "safety and stability" for banks because they view capital as a guard or cushion for absorbing losses (Abdel-Karim, 1996). The higher the capital adequacy ratio, the greater the level of unexpected losses a bank can absorb. However, a very 
high CAR will lead to investment problems, where banks will not have sufficient funds to invest in securities or subsidiaries. BoM's 2016 reports along with communication made to the public, mentioned that banks in Mauritius were generally financially sound and resilient during the year despite a sluggish economic growth. The domestic banking sector remains well capitalized with the aggregate capital adequacy ratio being higher than threshold regulatory level of $10 \%$ at $17.5 \%$ as at end-June 2016 .

In banking, the most important determinants of capital adequacy are the risks faced by banks (Aremu et al., 2010). Regulators require a certain amount of capital that banks must maintain with the level of risks they carry. Ahmad et al. (2009) assessed the major determinants of bank capital using unbalanced panel data set for eight years to investigate the implications of the 1997 Asian financial crisis. The test results suggested that there was a strong positive link between regulatory capital and bank management's risk-taking behaviour. Greater risk-taking activities by banks led to more regulatory capital. It was concluded that for a bank to be well-managed, CAR should be high. Furthermore, the financial ratios which relate capital to the corresponding banking risks have been usually used to regulate bank capital adequacy (Altunbas et al., 2000). They observed a positive relationship between risks and CAR. The banks held high level of capital to restrict risk-taking activities. Wen (2009) analysed the determinants of bank capital ratio for seven countries in East Asia for the period 2004 to 2007. The study also attempted to investigate the link between CAR and bank risk. Al-Sabbagh (2004) conducted a study to analyse the determinants of CAR by taking a sample of 17 banks in Jordan from 1995 to 2001. The results revealed that banks in Jordan should maintain or increase their CAR to enhance safety of the banking system, and the safety to depositors. In a study to determine the factors affecting the financial risk management efficiency for the Nigerian banking industry, Awojobi et al. (2011) used panel regression from 2003 to 2009 and took nine largest banks in terms of asset base Credit risk, liquidity risk, interest rate risk and market risk all had a positive relationship with CAR. However, empirical findings showed that those banks were under-capitalised and their risk management practices were poor. Raharjo et al. (2014) conducted a similar study to analyse the determinants of capital ratio of Indonesian banks. They used a multivariate panel regression model from 2004 to 2012. The results suggested that all the bank-specific variables had a positive link with CAR. The additional capital augmentation aimed to improve the readiness of Indonesia commercial banks in anticipation of increased risk. In general, it was found that the Indonesian banking sector maintained a strong risk position. Chakroun and Abid (2016) dealt with the issue of bank capital adequacy and risk management within a stochastic dynamic setting among banks in Tunisia. The pertaining analysis relied heavily on the stochastic dynamic modeling of such balance sheet items as securities, loans, and regulatory capital with stochastic interest rates. It was observed that Tunisian banks exceeded the minimum requirements and were adequately capitalized to maintain the appropriate capital amount level commensu- 
rate with the aggregate risk. Furthermore, Heydari and Abdoli (2015) studied the effect of credit risk management and capital adequacy on financial performance of business banks from 2009 to 2014 and showed a positive relationship between liquidity ratio and capital adequacy ratio with banks' performance. Along the same line, Olarewaju and Akande (2016) examined the determinants of capital adequacy in Nigerian quoted deposit money banks for the years 2005 and recommended the need for all affected banks to gear up and invest more on the significant factors that can lead to improvements in their capital adequacy in order to achieve viability, sustainability and stability in the long run. For the Indian Banking industry, Mohanty (2016) analyzed the essence of maintaining Capital adequacy ratio and the factors affecting the level of CAR. Similar results of strong positive correlation with factors such as Reserve Ratio, Debt to Equity Ratio, Return on Asset and Interest Income Ratio were obtained while liquidity was strongly and negatively correlated to CAR.

Klepczarek (2015) examined the factors affecting the Common Equity Tier 1 Ratio (CET1), being a measure of the relationship between core capital and the risk-weighted assets of banks. The research was based on a randomly selected sample from the group of banks examined by the European Central Bank (ECB) authorities. The ECB conducted stress tests assessing the CET1 Ratio with respect to the Basel III regulations. The findings confirmed the hypothesis about the impact of bank size and the risk indicators (risk-weight assets to total assets ratio and the share of loans in total assets) on banks' capital adequacy. They also presented strong effect of competitive pressure and the negative correlation between the CET1 Ratio and the share of deposits in non-equity liabilities, which might be explained by the existence of the deposit insurance system.

\section{Methodology}

This study adopts a dual approach and uses both primary and secondary techniques. Secondary data was obtained from income statements and statements of financial position of the selected banks in the sample for the period 2006 to 2016. Data from annual reports and other reports issued by the banks, as well as information from the Registrar of Companies were used. Ultimately, primary data was collected with the aid of a questionnaire.

The sampling plan calls for the choice of the banks and the number of banks that should be included in the research to obtain a valid result. Global Finance Mauritius (2016) identified The Mauritius Commercial Bank, State Bank of Mauritius, HSBC Bank (Mauritius) and Barclays Bank (Mauritius) as the systemically most important banks in Mauritius. In addition to these banks, Standard Chartered Bank (Mauritius), Standard Bank (Mauritius), Investec Bank (Mauritius), Banque des Mascareignes, Bank One, and MauBank, which are considered to be the largest banks based on their asset size, hasalso been included in the sample. Since the objective of this study is to analyse how competent the risk management framework has been before and after the 2007 financial crisis, data will be examined from 2006 to 2016 . The choice of this sample is 
as such, because only the above mentioned largest banks were incorporated before 2006. Also, based on the data from financial statements of each bank, the selected top banks account for $70 \%$ of the total assets of the Mauritian banking industry. Therefore, the sample which consists of ten banks in total will be used in the regression as well as in the survey.

\subsection{Model Specification}

The model is econometrically expressed as:

$$
Y_{i t}=\alpha+\beta_{1} C R i s k+\beta_{2} L Q R+\beta_{3} I S R+\beta_{4} F E R+\mu_{i}+\varepsilon_{i t}
$$

where $Y_{i t}$ refers to Capital Adequacy Ratio, $\alpha$ denotes the constant term, $\beta$ shows the coefficient of the variables, CRisk is Credit Risk, $L Q R$ stands for Liquidity Ratio, ISR is Interest Sensitivity Ratio, FER represents Foreign Exchange Risk, $\mu_{i}$ is the individual specific heterogeneity, that is the heterogeneity attributable to the idiosyncratic characteristics of the banks under consideration and finally $\varepsilon_{i t}$ denotes the error term.

Credit risk is regarded as an independent variable measuring a bank's exposure to counterparty risk. The risk is expressed as a ratio of net loans to total assets for bank (Awojobi et al., 2011). It measures the impact of loans in asset portfolio on capital. Since lending to customers is regarded as the most important source of income for banks, great importance is assigned to net loan when calculating credit risk. Difficulty for customers in repaying their debt increases the credit risk of banking institutions. Normally, the higher the net loan to asset ratio, the greater the credit risk.

Liquidity ratio is used to assess banks' liquidity risk. The latter arises where short term obligations cannot be met in case of a bankruptcy and a bank is forced to liquidate part of its fixed assets below their market value This ratio is considered because it is the most stringent and conservative ratio by measuring only the liquid assets over total liabilities.

Interest sensitivity ratio is used as a proxy of interest rate risk. The ratio measures the sensitivity of banks to interest rate fluctuations based on its repriceable assets and liabilities. According to Raharjo et al. (2014) an asset or liability is said to be interest rate sensitive within a specific time period if it will mature or be repriced within that time period. Interest sensitivity is computed as the ratio of Interest Sensitive Assets over Interest Sensitive Liabilities

The natural logarithm of Value at Risk (VaR) loss is used to estimate the potential foreign exchange loss arising from adverse movements in an ordinary market environment. The VaR position will be obtained in the financial risk management section of the banks' annual report.

Panel data regression is employed to analyse the efficiency of banks' risk management affected by the financial risks. Related studies such as Ahmad et al. (2009), Awojobi et al. (2011) and Bateni et al. (2014) have employed panel data regression framework to carry their work on capital adequacy in banks. Panel data will be used to investigate the relationship between the dependent variable, 
capital adequacy ratio (CAR) and the independent variables. Panel data methodology presented here is based on Awojobi et al. (2011) and Raharjo et al. (2014).

The panel data approach consists of both cross-sectional and time series statistical analysis. This provides more degrees of freedom and hence allows more efficient estimation. Collinearity is also reduced among variables as the combination of time series and cross section will add more variability. Another major characteristic of panel data is that it is able to cater for heterogeneity of individual cross sections. This is particularly essential when the cross sections have some distinctive characteristics or variables that are hard to observe and difficult to measure and hence not possible to include in the regression. The econometric form of the panel regression is:

$$
Y_{i t}=\alpha+\beta X_{i t}+\pi_{i t}\left(\pi_{i t}=\mu_{i}+\varepsilon_{i}\right)
$$

where " $i$ " denotes the cross-section dimension (banks) and " $l$ " denotes the time-series dimension (years). $\alpha$ is a constant term denoting intercept and $\beta$ is the estimating parameter. $X_{i t}$ is the explanatory variable of ith component. $X_{i t}$ is regarded to be exogenous if it is uncorrelated with the disturbance $\pi_{i t} \cdot \mu_{i}$ is the unobservable individual effect and $\varepsilon_{i}$ is the residual of disturbance.

\subsection{Survey Instrument}

A questionnaire has been designed to address some of the objectives of the study to further gauge into the techniques adopted by the Mauritian banks in managing the financial risks and to uncover their perspective on the importance of Basel framework and its contribution to the financial risk management field. The respondents are risk officers, managers, executives or other staffs who are well versed in the management of financial risks from the banks selected in the sample. One of the main issues faced with some respondents was the reluctance to answer some parts of the survey as they feared the disclosure of strict confidential information.

\section{Analysis}

\subsection{Descriptive Statistics}

Table 1 describes the performance of the banks due to exposure of risk factors such as credit risk, liquidity risk, interest rate risk and foreign exchange risk. The average capital adequacy ratio is indicated by a mean value of $14.3 \%$ among the banks. This highlights that the Mauritian banks maintain a sound profile since they maintain CAR higher than the threshold of $10 \%$ as required by the Basel. The credit risk shows a mean value of $62 \%$ with a standard deviation of 0.85 which implies a high credit ratio, as $62 \%$ of total assets are diluted on loans to customers. On the other hand, the liquidity risk which indicates that all the banks are sufficiently liquid with a mean threshold of $31 \%$. The mean value of interest rate risk is $2 \%$ and foreign exchange risk at $9 \%$. This indicates that the impact of interest rate risk is lowest on the capital adequacy position of the 
Table 1. Descriptive statistics.

\begin{tabular}{cccccc}
\hline Statistics & CAR & Credit Risk & Liquidity Risk & Interest Rate Risk & $\begin{array}{c}\text { Foreign } \\
\text { Exchange Risk }\end{array}$ \\
\hline $\begin{array}{c}\text { Mean } \\
\text { Standard }\end{array}$ & 0.1428 & 0.6259 & 0.3125 & 0.0221 & 0.0991 \\
Deviation & 0.03852 & 0.8526 & 0.5985 & 0.3641 & 0.0128 \\
\hline
\end{tabular}

banks. The same can be noted for the foreign exchange risk of the banks. It can be concluded that the banks are sufficiently capitalized at a minimum value of $36 \%$ although they provide a high level of credit at $62 \%$, diluting their assets in loans and maintaining a liquidity position of $31 \%$. Also, they are least affected by interest rate risk and foreign exchange risk.

Furthermore, the trend of CAR for the period 2006 to 2016 suggests that the majority of the banks are maintaining a CAR between $10 \%$ to $20 \%$ and preserving nearly the same figures each year, except Investec Bank (Mauritius), which is clearly overshooting the threshold of $10 \%$. The discrepancies in the yearly CAR of the bank can be explained by the change in investment strategies as from 2008.

\subsection{Statistical Tests for Model Selection}

The variance inflation factor (VIF) is a method of detecting the problem of multicollinearity. Which occurs when two or more regressors in the model are correlated and provide redundant information about the response. It increases the standard errors of the coefficients making them statistically insignificant. The VIF obtained results less than 10 suggesting absence of multicollinearity. Furthermore, to select the Panel Data model to be adopted, the Breusch-Pagan is used to test for heteroskedasticity in a linear regression model. It tests whether the estimated variance of the residuals from a regression are dependent on the values of the independent variables. According to Baltagi (1995), OLS model may become inefficient in the presence of heteroscedasticity. A p-value of greater than $5 \%$ indicates that heteroskedasticity is absent and the OLS model is appropriate. However, the p-value generated by the Breusch-Pagan test in our study was zero (0.000). This confirmed the presence of heteroskedasticity and the Gneralised Least Square (GLS) model was preferred over the OLS model. The GLS model consists of fixed effect model and random effect model. Therefore, in order to determine which of the fixed or random model to use, the Hausman Specification Test was carried out. Hausman test normally checks if the variance in the estimates of the random and fixed effect models is significant to cause biasness of the modelled parameters. If the variance is statistically significant, there is a probability of unobserved individual heterogeneity being uncorrelated to the independent variables, implying that the random effect model estimates are preferred. The Hausman test yielded a result of 0.4175 and failed to reject the null hypothesis that the random error component is not correlated to the regressors. Hence, the random effect model was more appropriate than the 
fixed effect model. The random effect model specification assumes that $\mu \mathrm{i}$ are random and are not correlated with explanatory variables. In this model, the unobserved heterogeneity is captured by the error component $\mu \mathrm{i}$ and intercept is the same for all cross-sections.

Furthermore, The Wald Chi square-test which is used to test the statistical significance of each coefficient in the model, gives a p-value of zero (0.000). Thus, it is certain that our model is efficient and there is indeed a relationship between the dependent variable and the regressors. The R-squared, typically read as the "percent of variance explained", measures the overall fit of the model. The R-squared that is explained by our explanatory variables, has generated a value of 0.6796 . This is considered to be fairly high because we have taken only the bank risk factors as compared to previous studies which employed other bank-specific determinants in addition of the risk variables, for example, Awojobi et al. (2011) and Bateni et al. (2014), where the values were 0.881 and 0.7715 respectively. Furthermore, a similar study performed by Abdalla \& Obeidat (2013) obtained an R-squared value of just 0.61 taking only three risk factors and other bank-specific variables. As such, it is observed that around $68 \%$ of the variation of CAR can be explained by the changes is the risk variables for our model.

The panel data unit-root test has been conducted to determine whether our datasets have unit roots or are deem to be stationary. The unit-root test comprises of two hypotheses; whereby the null hypothesis states that the data contains a unit root and the alternate hypothesis depicts that the panels are stationary. The Levin-Lin-Chu has been implemented taking into account the sample frame, and the test generated a result of -0.1274 thereby rejecting the null hypothesis. Since the p-value is less than $5 \%$, it can be concluded that the panels in our data-sets are stationary.

\subsection{Regression Output}

Table 2 summaries the output for the regression analysis.

The regression confirmed the positive relationship between credit risk and Capital Adequacy Ratio with a positive coefficient of 1.53. A perfect p-value of zero (0.000) underlines the high significance of the result. This is in line with Basel capital adequacy requirement for risk mitigation, which states that efficiency of risk managing a bank's loan portfolio can be achieved through capital augmentation. If credit risk is increasing, banks normally raise their CAR either by introducing more regulatory capital or lessening their risk-weighted assets to avoid taking too much risk. Al-Sabbagh (2004) and Awojobi et al. (2011) also found the same positive link between credit risk and CAR, but Abdalla \& Obeidat (2013) found an inverse non-significant relationship between the regress or and bank capital adequacy. In addition, the model has considered credit risk as the foremost factor influencing CAR because of its parameter of 1.53 , the highest in our model. Thus, credit risk is the variable which has the highest impact on 
Table 2. GLS random effect regression results.

\begin{tabular}{ccc}
\hline & Coefficient & P Value \\
\hline Credit Risk & $1.529642^{*}$ & 0.000 \\
Liquidity Ratio & $0.6293477^{\star}$ & 0.003 \\
Interest Sensitivity Ratio & $0.1331026^{*}$ & 0.012 \\
Foreign Exchange Risk & $0.0492665^{\star}$ & 0.049 \\
\hline
\end{tabular}

Prob $>$ chi $^{2}=0.0000 ;$ R-squared $=0.5681$.

CAR. This supports the fact that credit risk is the most important risk faced by banks. More than $65 \%$ of Mauritian banks' assets consist in lending to public. Consequently, measures for mitigating credit risk are of significant importance for banks in their risk management. A significant rise in CAR to absorb potential losses is therefore substantiated in the context of Mauritian banks. The following graph depicts the Lowess Smoother for leverage and CDS spread.

The bandwidth of 0.8 indicates that $80 \%$ of the data are considered for each observation in order to find the fitted point. The Lowess curve confirms the high coefficient of the parametric regression and there is a conspicuous highly positive link between credit risk and CAR. The higher the credit risk, the larger the capital adequacy will be. Unexpectedly, most banks have a credit risk ratio in the range 0.6 to 0.8 which is considerably high. This means that, despite the recent financial crisis, Mauritian banks are still maintaining high credit risk ratios. One possible reason is that they have not been much affected by the crisis owing to their efficient risk management practices. Another probable explanation is that the banks are concentrating more on profitability to the detriment of credit risk. They are keeping on granting huge amount of loans to be more profitable, without paying much attention to the probability of default. In addition, it is interesting to note that the curve is concave and steeper in the range 0.3 to 0.5 and shallows from thereon. This can be explained by the fact that, the largest powerful banks can command high credit risk ratios due to their impeccable credit worthiness and high capitalisation to compensate for losses. The CAR rises by a large amount to account for the higher credit risk.

The hypotheses stresses that high liquidity ratio signifies low liquidity risk, and to maintain low liquidity risk, CAR must be increased. Hence, elevation in liquidity ratio should normally contribute to higher CAR. Liquidity ratio has been used as a proxy just as in Awojobi et al. (2011) and based on our results; one unit rise in liquidity ratio will lead to 0.629 unit growth in CAR. A p-value of almost zero (0.003) highlights the significance of the results. It shows that Mauritian banks' risk management practices are positively associated with their liquidity position. This is in line with Angbazo (1997) who found that an increase in bank liquidity has a positive and significant impact on CAR through its effect on the changes in required rate of return on bank shares. As the proportion of funds invested in cash and cash equivalents, considered as the most liquid assets increases, bank liquidity risk must decline. Awojobi et al. (2011) also 
discovered that a bank with low liquidity will face difficulty to fulfil its short term obligations to customers. Therefore, banks must have to liquidate part of their assets or take from capital to minimise liquidity risk. However, Shingjergji \& Hyseni (2015) observed a negative relationship between liquidity ratio and CAR, whereby an increase in loan to deposit ratio led to a reduction in capital adequacy in the Albanian banking system.

A positive or negative relationship was expected to be found between interest sensitivity ratio and CAR, depending on the interest rate from 2006 to 2016. The regression has generated a coefficient of 0.133 . This is because a deteriorating interest rate level has affected the interest sensitive assets. As illustrated in Figure 1, there has been a constant descent in the level of interest rate from 2006 to 2016. The declining interest rate was detrimental to the interest sensitivity ratio of greater than 1.0 (asset sensitive). Lower interest rates have adverse impact on interest sensitive assets thereby diminishing income as mentioned by Raharjo et al. (2014). Therefore, to reduce interest rate risk, CAR should increase. In addition of the positive link, the p-value of 0.009 underlines the high significance of the result. A numerical change of 1 in interest sensitivity ratio will lead to 0.133 unit change in CAR. Conversely, Altunbas et al. (2000) found a negative relationship between interest sensitivity gap and CAR. A plausible explanation is that, in Altunbas et al. (2000) study, interest sensitivity gap was less than 1.0 or perhaps interest rate level was rising.

The last factor put forward by our model is the foreign exchange risk. The hypothesis states that the relationship of foreign exchange risk to CAR is positive since higher exposure to foreign losses must be compensated by increase in capital or decrease in risk-weighted foreign assets. This prediction is confirmed by our regression with a positive coefficient of 0.049 . It means that a unit rise in foreign exchange risk will lead to 0.049 rise in CAR. It can be seen that foreign exchange risk is the variable which has the least impact on CAR. However, the p-value of 0.049 does not add considerable weight to the significance of the result. Yet, as the value is below $5 \%$, we can say that the variable is statistically significant. This follows the study of Awojobi et al. (2011), suggesting that when a banking firm is exposed to currency uncertainties, risk management would be efficient at the instance where sufficient reserve capital is on standby. Hence, well capitalized Mauritian banks are in better position to sustain operation at the windfall of the foreign currency changes.

\subsection{Survey Output}

Figure 2 clearly shows that the Mauritian banking system accord very high importance in the management of credit risk, while lesser significance is given to manage liquidity, interest rate and foreign exchange risks. Adequately managing credit risk in banks is critical for their survival and growth. The issue of credit is of greater concern because of the higher levels of perceived risks resulting from some of the characteristics of clients and business conditions that they find themselves in. Subsequently, they grant $83 \%, 53 \%$ and $24 \%$ of very high 


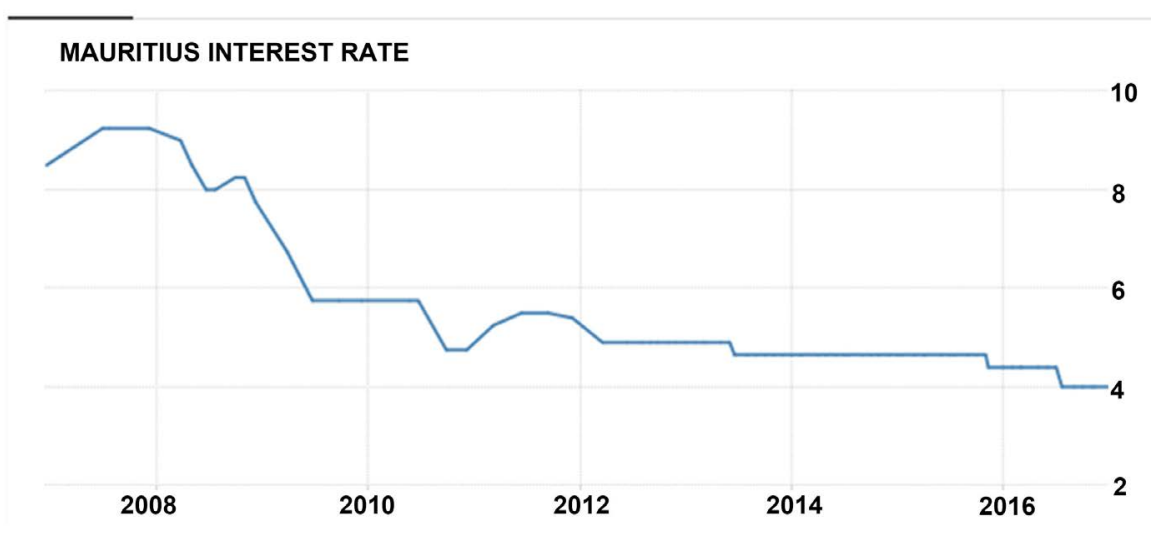

Figure 1. Level of interest rate from 2006 to 2017. Source: www.tradingeconomics.com, Bank of Mauritius 2018.

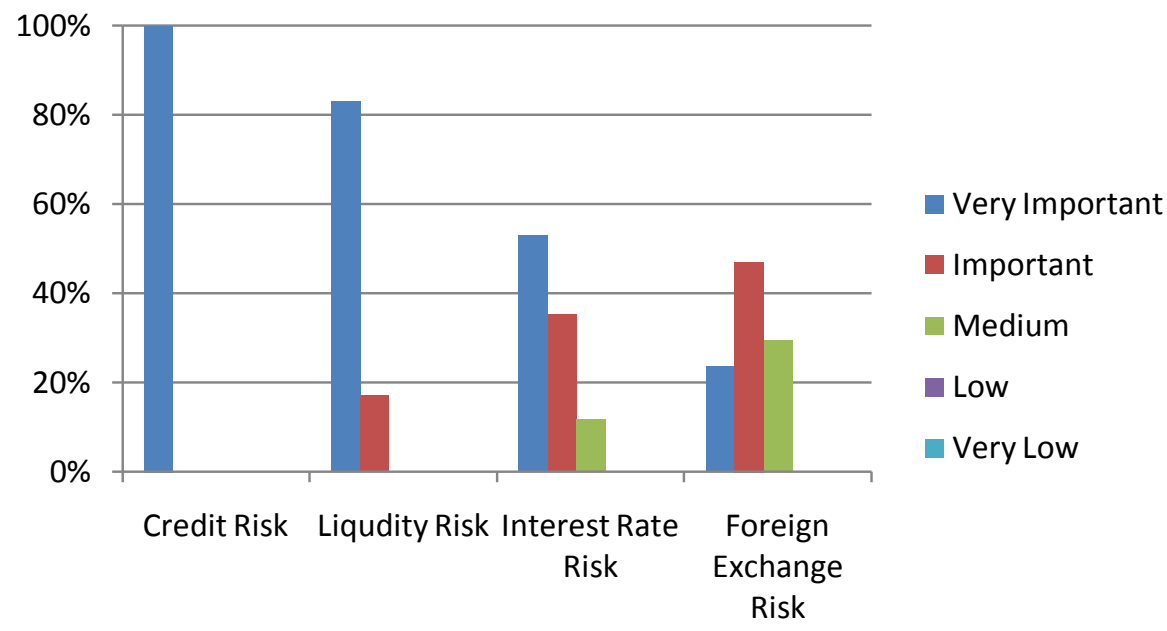

Figure 2. Importance to manage financial risks.

importance for the management of liquidity risk, interest rate risk and foreign exchange risk respectively.

Banks use a number of methods, ranging from basic calculations to highly sophisticated modelling, to manage financial risks. It is important for them to adopt a technique that is most proper and to take into consideration the nature, scale and complexity of their activities. Almost $50 \%$ of the banks stressed that they manage credit risks through credit ratings or rating tools. The institutions map their system to Fitch and Moody's international rating scales. In addition, 3 banks regard credit concentration as a strategy for credit risk management. Concentration limits are used by the Mauritian banks in order to estimate their exposure to credit risk. In addition, 6 banks state that it is important to manage credit/loan portfolios and risk weighted portfolios through various risk ratios to have in-depth credit assessment on borrowers. Credit risk ratios such as credit loss ratio, impairment loss ratio, net loan to total asset ratio, loan loss reserve ratio amongst others are calculated by the firms to monitor and manage credit risk. 
8 banks manage liquidity risk through financial ratios. Ratio analysis is the traditional method of managing liquidity which includes cash reserve ratio, liquid asset to total asset ratio, deposit to loan ratio and liquidity coverage ratio. Additional, more than half of respondents held treasury unit as the one responsible to administer liquidity risk by managing cash flow operations. Their banks have an Asset-Liability Committee (ALCO) which is responsible for day to day cash flow analysis. Asset and Liability Management (ALM) is another process highlighted by the respondents for handling liquidity risk that arises because of liquidity mismatch of assets and liabilities.

Undoubtedly, for interest rate risk management, all banks make use of repricing analysis/rate sensitivity analysis which is regarded as the most efficient method to measure and manage this risk. By applying floating interest rates linked to an index, repricing gap analysis techniques are used to monitor structural interest rate risk by the Mauritian banks. A positive gap expresses a situation where assets re-pricing exceed liabilities re-pricing. The larger the gap, the greater is the interest rate risk. In our regression, we have employed rate sensitivity analysis to calculate the risk. In addition of gap analysis, four banks point out that they also utilise stress testing to control interest rate risk.

Each bank uses Value-at-risk (VaR) technique to measure and manage the level of exchange rate risk over a specific time frame. The firms calculate VaR using 10 days holding period and an expected tail-loss methodology, which approximates a $99 \%$ confidence level. This would mean that only once in every 100 trading days, the banks would expect to incur losses greater than the VAR estimates, or about two to three times a year. The use of 10 days holding period and a one-year historical observation period are in line with the Basel II recommendation. Moreover, 3 banks claim that they closely monitor foreign portfolios and limit hedging exposure to avoid absorbing too much loss.

When questioned if the methods have been efficient to manage the different risks, all the banks strongly agree that these methods have contributed to the efficiency of the risk management framework of their respective bank.

The survey also uncovered the risk management framework of banks is in line with the Basel II directives, all the respondents give a positive answer. All the respondents hold capital adequacy ratio as an important indicator of the risk management efficiency of their respective banks. The Basel framework attributes great importance on capital adequacy, where capital augmentation will help banks to insure against potential risk-taking. The majority of participants were agreeable with the statement that "CAR should be increased further beyond its original amount of $8 \%$ " as a higher CAR means that they have more reserve for meeting all commitments on time. Those responding negatively explained that their banks prefer to invest in subsidiaries, instead of holding huge amount of funds as cushion to absorb losses in case of emergency.

The survey seeks to know if the implementation of the Basel III framework will be successful in the Mauritian banking industry in regards of the recent financial distress. 7 banks agree that this set of standards will be a success as it will 
contribute enormously to the mitigation of risk as well as striking a stable balance between risk and return. One bank cited "Banking firms are becoming merely' 'puppets' of the government bodies. Basel III shall open new horizons to attain international standards, and enhance supervision and transparency." In addition, liquidity is greatly highlighted in most aspect of the economy; therefore, global liquidity standards are a must. The introduction of the directives will surely make Mauritian banks more resilient with the minimum capital threshold, and the high emphasis on leverage ratio will strengthen the shield to insure against potential risks. One bank somewhat disagrees to the same question by pointing out that the introduction of the Basel framework "is not appropriate for Mauritian market". A plausible reason is that it will limit business opportunities as more funds will be kept as capital to absorb losses in case of future crises, thereby decreasing investment chances. Additionally, the respondent, emphasising on the recent downgrade of MCB and SBM, states that Basel III will hurt the banking sector. The latter also mentions that its costs will definitely outweigh the benefits. A large bank takes a neutral position declaring that implementation of the Basel III is "highly dependent on the balance sheets of the banks in Mauritius and their future expansion strategy". For example, Bramer Banking Corporation Ltdwould have never been able to meet the criteria's under Basel III. Hence a segregation of performing banks and banks with deficiencies in their balance sheet is the main area of focus for Basel III to be successful.

\subsection{Discussion}

All banks agree that they are exposed to the four types of financial risks on a daily basis, and as a result, these risks should be managed efficiently. This finding is in line with the parametric regression which held the four risks as statistically significant variables in our model. A p-value of less than 0.05 for each predictor, affirmed that credit, liquidity, interest and foreign exchange risks have an impact on a bank's overall risk profile and must be managed and reduced to avoid assimilating excessive losses and become insolvent.

Moreover, the findings from the survey revealed that very high importance is accorded in the management of credit risk, followed by liquidity risk, interest rate risk and least significance is given to control foreign exchange risk. This bodes well with the Lowess non-parametric curve which is steeper for credit risk and shallower for other types of risks; foreign exchange risk having the shallowest curve. As shown by non-parametric graph of credit risk, CAR should rise to a significant amount in order to compensate for potential credit losses. The high elevation of the curve supports the fact that strong emphasis must be given to the management of default risk. On the other hand, the Lowess graph of foreign exchange risk generated the smallest gradient highlighting the least significance in managing currency exposures. The Mauritian banks classify credit risk as the risk that has the highest impact on the efficiency of risk management. Lagging behind are liquidity risk, interest rate risk, and foreign exchange risk (least impact). Without any doubt, this is line with our regression outcome, whereby 
credit risk was the variable which had the highest coefficient, 1.639, meaning that it would cause capital adequacy to rise considerably. Foreign exchange exposure, conversely, with its parameter of 0.056 had the least effect on CAR.

Respondents agreed that the capital adequacy ratio is an important indicator of the risk management efficiency and seven banks concurred that CAR should be increased beyond its original amount of $8 \%$. CAR has been used as a dependent variable in our regression model and has been considered as a measure of risk management efficiency. The regression results exhibited how an increase in CAR has acted as a shield against the different financial risks. Consequently, it has been found that, the higher the CAR, the better the risk management framework of banks. Therefore, it is safe to say that this finding from the survey reaps the same underlying result as our parametric regression.

\section{Conclusion}

The main objective of this study was to determine the relationship between the financial risks and the risk management efficiency in Mauritian banks. Panel regression methodology was used to test the significance of the factors put forward by the structural models. A sample of 10 banks was used for the purpose of this regression. The regression results have shown that all four predictors considered, credit risk, liquidity risk, interest rate risk and foreign exchange risk had a significant and positive impact on CAR. Ultimately, the survey performed to support the regressions, substantiated the main results and also shed light on the methods used by banks to manage the various financial risks.

Empirical findings based on this study suggested that risk management in the Mauritian banking sector has been efficient. As expected, credit risk showed a positive and high impact on capital position of Mauritian banks. By implication, an average Mauritian bank is efficient in managing its credit portfolio since evidence showed that they have sustained adequate capital for exposures from credit activities. This is similar for liquidity, interest rate and foreign exchange risk as well; the local banks hold adequate level of capital as buffer to insure against potential risks. The banks are ready to increase their CAR in case of emergency. Furthermore, the results from the survey revealed that the banking sector employ proper methods and have adequate tools and techniques to manage and monitor financial risks on an ongoing basis. As a result, banks in Mauritius should firstly establish sound risk management policies to administer the high level of non-performing loans which may lead to bank failures. They should also develop a consistent and comprehensive system (netting process) to mitigate credit risk off-balance by making use of futures, options and swaps. Additionally, the appointment of bank chief executive officers should not be restricted to "friends of government" in the banking system. Recent cases have shown that some have only enriched themselves to the detriment of their customers. The controversies at the Bramer Banking Corporation Ltd. made depositors to lose confidence in the whole banking industry.

Although, the local risk management framework is in line with Basel II rules, 
it may still be subject to adverse impact caused by the risks looming in the financial market. The Mauritian banks may be perceived to be strong enough to absorb shocks, but future financial crises may prove otherwise. The banking institutions should continue to endeavour towards implementing effective risk management practices to benefit from their positive aspects. They must be ready to implement the Basel III framework which will give a new dimension on how to manage risks more efficiently and as such, consolidate a bank's risk position. Risk management should be treated of a lesser compliance burden but more of a value added function. Shifting to a more transparent environment, low involvement in too volatile economics, and investment in technology will surely help to improve the risk management framework of the local banking industry. An augmentation in capital adequacy aims to improve the efficiency of the risk management framework of Mauritian banks in anticipation of increased risk and surprises in the future due to fluctuations in macroeconomic conditions. Changes in the bank capital ratio regulation must be followed by micro-prudential (individual bank) supervision. It is intended to prevent the bank's management to invest in high risk assets to offset the additional cost of capital.

The study aimed to determine the efficiency of risk management in the Mauritian banking sector before and after the recent financial crisis. In that respect, the study covered a period of eleven years (2006 to 2016). However, out of the 22 banks in the local banking industry, only ten largest banks were incorporated before 2006. This has limited our sample size and therefore, the study was unable to provide a complete picture of the whole banking sector. From 2006 to 2008, banks computed and reported their capital adequacy ratio according to Basel I framework, while for 2009 to 2016, CAR was based on Basel II directives. The difference in the computation of CAR affected the statistical significance of our data. Further research should be undertaken on the applicability of Basel III. While the research has emphasised on CAR based on Basel II directives, it is pertinent to assess the applicability of Basel III framework to the banking system of Mauritius in order to yield more accurate results. Another direction for further research on this topic is to specify and compare the different types of banks, which in addition of commercial banks consist of joint ventures, asset management and also private equities, in order to investigate to what extent capital adequacy of these banks varies to absorb potential risks.

\section{Conflicts of Interest}

The authors declare no conflicts of interest regarding the publication of this paper.

\section{References}

Abdalla, K. A., \& Obeidat, S. F. (2013). Determinants of Capital Adequacy in Commercial Banks of Jordan an Empirical Study. International Journal of Academic Research in Economics and Management Sciences, 2, 44-58. https://doi.org/10.6007/IJAREMS/v2-i4/53 
Abdel Karim, R. A. (1996). The Impact of the Basel Capital Adequacy Ratio Regulation on the Financial and Marketing Strategies of Islamic Banks. International Journal of Bank Marketing, 14, 32-44. https://doi.org/10.1108/02652329610151368

Ahmad, R., Ariff, M., \& Skully, M. (2009). The Determinants of Bank Capital Ratios in a Developing Economy. Asia-Pacific Financial Markets, 15, 255-272.

https://doi.org/10.1007/s10690-009-9081-9

Al-Sabbagh, N. (2004). Determinants of Capital Adequacy Ratio in Jordanian Banks. Master's Thesis, Irbid, Jordan: Yarmouk University.

Altunbas, Y., Liu, M., Molyneux, P., \& Seth, R. (2000). Efficiency and Risk in Japanese. Journal of Banking \& Finance, 24, 1605-1628.

https://doi.org/10.1016/S0378-4266(99)00095-3

Anbar, A. (2006). Credit Risk Management in the Turkish Banking Sector: A Survey Study. Bursa, Turkey: Uludag University Press.

Angbazo, L. (1997). Commercial Bank Net Interest Margins, Default Risk, Interest-Rate Risk, and Off-Balance Sheet Banking. Journal of Banking \& Finance, 21, 55-87. https://doi.org/10.1016/S0378-4266(96)00025-8

Aremu, O., Suberu, J., \& Oke, J. (2010). Effective Credit Processing and Administration as a Panacea for Non-Performing Assets in the Nigerian Banking System. Journal of Economics, 1, 53-56. https://doi.org/10.1080/09765239.2010.11884924

Awojobi, O., Amel, R., \& Norouzi, S. (2011). Analysing Risk Management in Banks: Evidence of Bank Efficiency and Macroeconomic Impact. Famagusta, Cyprus: Eastern Mediterranean University.

Baltagi, B. H. (1995). Editor's Introduction Panel Data. Journal of Econometrics, 68, 1-4. https://doi.org/10.1016/0304-4076(95)90009-8

Bateni, L., Vakilifard, H., \& Asghari, F. (2014). The Influential Factors on Capital Adequacy Ratio in Iranian Banks. International Journal of Economics and Finance, 6, 108-116. https://doi.org/10.5539/ijef.v6n11p108

Beltratti, A., \& Stulz, R. M. (2012). The Credit Crisis around the Globe: Why Did Some Banks Perform Better? Journal of Financial Economics, 105, 1-17.

https://doi.org/10.1016/j.jfineco.2011.12.005

Berger, A. N., \& Bouwman, C. H. S. (2013). How Does Capital Affect Bank Performance during Financial Crises? Journal of Financial Economics, 109, 146-176.

https://doi.org/10.1016/j.jfineco.2013.02.008

Bonfim, D., \& Kim, M. (2012). Liquidity Risk in Banking: Is There Herding. European Banking Center Discussion Paper No. 2012-024. https://doi.org/10.2139/ssrn.2163547

Burke, Q. L., \& Warfield, T. (2014). Bank Interest Rate Risk Management and Valuation of Earnings. https://doi.org/10.2139/ssrn.2467698

Eljelli, M. A. (2004). Liquidity-Profitability Tradeoff: An Empirical Investigation in Emerging Market. International Journal of Commerce and Management, 14, 48-61. https://doi.org/10.1108/10569210480000179

Harris, M., Opp, C. C., \& Opp, M. M. (2014). Higher Capital Requirements, Safer Banks? Macroprudential Regulation in a Competitive Financial System.

https://doi.org/10.2139/ssrn.2467761

Ojo, A. (2008). Efficiency of Capital Regulation for Nigerian Banks. Nigerian Journal of Economics and Social Science, 51, 667-679.

Papaioannou, M. (2006). Exchange Rate Risk Measurement and Management: Issues and Approaches for Firms. South-Eastern Europe Journal of Economics, 2, 129-146.

Raharjo, P. G., Hakim, D. B., Manurang, A. N., \& Ahmad, T. N. (2014). Determinant of 
Capital Ratio: A Panel Data Analysis on State-Owned Banks in Indonesia. M.Sc. Thesis, Bogor, Indonesia: Bogor Agriculture University.

Sabri, M. H. (2011). Foreign Exchange Risk Management in Commercial Banks in Pakistan. B.Sc. Thesis, Lahore, Pakistan: The University of Lahore.

Scannella, E., \& Bennardo, D. (2013). Interest Rate Risk in Banking: A Theoretical and Empirical Investigation through a Systemic Approach (Asset \& Liability Management). Business Systems Review, 2, 59-79.

Shingjergji, A., \& Hyseni, M. (2015). The Determinants of Capital Adequacy Ratio in the Albanian Banking System during 2007-2014. International Journal of Economics, Commerce and Management, 3, 1-10.

Wen, T. C. (2009). The Determinants of Bank Capital Ratio in East Asia. Master's Thesis, Malaysia: University of Malaysia. 